\title{
Molecular Cloning and Recombinant Expression of the VP28 Carboxyl-Terminal Hydrophilic Region from a Brazilian White Spot Syndrome Virus Isolate
}

\author{
Patricia Braunig, Rafael Diego da Rosa, Caroline Heidrich Seibert, Mariana Borsa, \\ Patricia Hermes Stoco, Edmundo Carlos Grisard and Aguinaldo Roberto Pinto* \\ Departamento de Microbiologia, Imunologia e Parasitologia; Universidade Federal de Santa Catarina; \\ 88040-900; Florianópolis - SC - Brasil
}

\begin{abstract}
In the present study, a fragment of the VP28 coding sequence from a Brazilian WSSV isolate (BrVP28) was cloned, sequenced and expressed in E. coli BL21(DE3) pLysS strain in order to produce the VP28 carboxyl-terminal hydrophilic region. The expression resulted in a protein of about $21 \mathrm{kDa}$, which was purified under denaturing conditions, resulting in a final highly purified BrVP28 preparation. The recombinant protein obtained can be used in several biotechnology applications, such as the production of monoclonal antibodies which could be used in the development of diagnostic tools as well as in the studies on the characterization of white spot syndrome virus (WSSV) isolated in Brazil.
\end{abstract}

Key words: WSSV, VP28, recombinant protein, penaeid shrimp

\section{INTRODUCTION}

White spot syndrome virus (WSSV) is one of the most serious viral diseases affecting the cultured shrimp worldwide (Flegel, 2007; Lo et al., 1996). This lethal virus causes the formation of white spots in the exoskeleton under the carapace and can infect not only the penaeid shrimps, but also other marine and freshwater crustaceans (Lo et al., 1996). The first outbreak of WSSV began to occur in Asia during the mid-1990s and later in the Americas in late 1990s, causing massive mortality rates in shrimp farms (Lightner, 2003). Since 2004, WSSV outbreaks have been reported in southern Brazil, causing losses estimated at several million dollars per year (Aphis-Usda, 2005).
WSSV consists of a large enveloped virus, ovoidto-baciliform in shape, containing a circular double-stranded DNA genome of $300 \mathrm{~kb}$ with approximately 180 putative open reading frames (Marks et al., 2004). Based on its unique genetic information and morphological features, WSSV represents a novel genus of DNA viruses, Whispovirus, belonging to the family Nimaviridae (van Hulten et al., 2001). This virus contains five major structural proteins, located in the viral envelope (VP19 and VP28) and in the nucleocapsid (VP15, VP24 and VP26). VP28 ( 22 $\mathrm{kDa})$ is the most abundant structural protein present in the envelope (Tang et al., 2007) and shows no similarity with other known proteins, except with some structural proteins of WSSV

*Author for correspondence: pintoar@ccb.ufsc.br 
(Robalino et al., 2006). This envelope protein was suggested to bind to shrimp cells, playing a crucial role in the viral penetration (Yi et al., 2004). Moreover, it has been shown that antibodies antiVP28 can neutralize the virus and block the viral infection (Yi et al., 2004). However, the mechanisms of virus entry into cells are still unknown.

The highly conserved nature of WSSV structural proteins enables the production of recombinant proteins for different applications, such as the production of poly and monoclonal antibodies that can be employed in immunodiagnostic assays, such as immunochromatographic kits (Wang and Zhan, 2006). Since currently there is no effective treatment for shrimp viral diseases, and vaccines cannot be developed and used in shrimp aquaculture due to the lack of adaptive immune system in crustaceans (Liu et al., 2009), rapid diagnosis is one of the most valid strategies to curtail the WSSV infection. Moreover, structural recombinant WSSV proteins can be used in order to understand the mechanisms of WSSV infection, morphogenesis and interaction with host molecules (Tang et al., 2007).

WSSV has been isolated from different geographic regions, such as Korea, Thailand, China and Americas (Lightner, 2003). Although the WSSV disease had been detected in Brazil since 2004, no reports concerning the characterization of Brazilian isolates were found in the literature. In the present study, a fragment of the VP28 gene (BrVP28) from a Brazilian WSSV isolate was cloned in order to produce its carboxyl-terminal hydrophilic region.

\section{MATERIALS AND METHODS}

WSSV-infected shrimps (Litopenaeus vannamei) were obtained from the shrimp farms in Santa Catarina state, southern Brazil. Genomic DNA was extracted from the infected shrimp cephalothoraxes by standard phenol-chloroform extraction method (Sambrook et al., 1989). DNA concentration was assessed by spectrophotometry and agarose gel electrophoresis. With the aim to produce the VP28 hydrophilic carboxyl-terminal portion, the VP28 deduced amino sequence from different WSSV isolates published on GenBank were analyzed by ProtScale software using Kyte and Doolittle method http://www.expasy.ch/tools/protscale.html). The analysis indicated the presence of a high hydrophobic portion at the amino-terminal region, which was excluded during the amplification process. Specific primers flanking the putative hydrophilic region were designed based on the VP28 sequence from an Indian WSSV isolate (GenBank: DQ681069).

Part of the VP28 coding sequence was amplified by polymerase chain reaction (PCR) using the primers VP28F (5, CATATGAATCACAACACTGTGACCAAGAC CA 3') and VP28R (5' ATAGGATCCAGCACGATTTATTTACTC 3'), generating the fragment named BrVP28. The underlined nucleotides in the sense strand indicate the location of a NdeI site, while those in the antisense strand indicated the location of a $\mathrm{BamHI}$ site. The PCR amplification was performed in a final volume of $25 \mu \mathrm{l}$ containing $1 \mathrm{x}$ reaction buffer, $0.2 \mathrm{mM}$ of a dNTP mixture, $1.5 \mathrm{mM}$ $\mathrm{MgCl}_{2}, 1 \mu \mathrm{M}$ of each primer, 1 unit of Taq DNA Polymerase (Invitrogen) and $20 \mathrm{ng}$ of DNA template. The PCR reaction was conducted with an initial denaturation step at $95^{\circ} \mathrm{C}$ for $5 \mathrm{~min}$, followed by 30 cycles of denaturation at $95^{\circ} \mathrm{C}$ for $40 \mathrm{~s}$, annealing at $60^{\circ} \mathrm{C}$ for $45 \mathrm{~s}$ and extension at $72^{\circ} \mathrm{C}$ for $1 \mathrm{~min}$, with a final extension step at $72^{\circ} \mathrm{C}$ for $5 \mathrm{~min}$. The amplification products were resolved in $1 \%$ agarose gel, stained with ethidium bromide, visualized in a transilluminator and digitally recorded. Subsequently, PCR products were cloned into pGEM-T-Easy vector (Novagen) and the recombinant plasmid (pGEM-TeasyBrVP28) was used to transform Escherichia coli DH5 $\alpha$ competent cells. The transformed cells were selected on amplicillin-containing LB plates (100 $\mu \mathrm{g} \mathrm{mL}^{-1}$ ) and screened by colony PCR using the above mentioned primers.

The pGEM-Teasy-BrVP28 plasmid was digested and the excised fragment BrVP28 was cloned into the pET-14b vector (Novagen) at the NdeI and BamHI sites, generating the plasmid pET14bBrVP28. The fragment was inserted downstream and in-frame with a coding sequence corresponding to a histidine tag, and was further sequenced in both the directions. Identity check was performed by the similarity analysis of the nucleotide and deduced amino acidic sequences obtained through the Expasy proteomic server (http://ca.expasy.org/) using the Blast algorithms (http://blast.ncbi.nlm.nih.gov/). The deduced amino acid sequence was aligned with VP28 protein sequences from other isolates using the 
ClustalX program in an attempt to identify the variability within the fragment chosen for expression.

With the aim to produce the recombinant BrVP28, pET14b-BrVP28 plasmid was used to transform $E$. coli BL21(DE3)pLysS strain. Single positive colonies were picked and cultured overnight at $37{ }^{\circ} \mathrm{C}$ in $10 \mathrm{~mL}$ of $\mathrm{LB}$ medium supplied with ampicillin $\left(100 \mu \mathrm{g} \mathrm{mL}^{-1}\right)$ and chloraphenicol (34 $\left.\mu \mathrm{g} \mathrm{mL}^{-1}\right)$. One aliquot of $5 \mathrm{~mL}$ of the overnight culture were inoculated into $150 \mathrm{~mL}$ of the same medium and were grown at $37^{\circ} \mathrm{C}$ until an $\mathrm{OD}_{600 \mathrm{~nm}}$ $\sim 0.5-0.7$. Cultures were then induced with $1 \mathrm{mM}$ IPTG (isopropyl- $\beta$-d-thiogalactopyranoside) and incubated at $37^{\circ} \mathrm{C}$ for further $4 \mathrm{~h}$. The induced cultures were harvested by centrifugation $(1,000 \mathrm{x}$ $g, 10 \mathrm{~min}, 4^{\circ} \mathrm{C}$ ) and the resulting cell pellet was suspended in $5 \mathrm{~mL} \mathrm{~g}^{-1}$ of denaturing lysis buffer $(8$ $\mathrm{M}$ urea, $100 \mathrm{mM} \mathrm{NaH} \mathrm{PO}_{4}, 100 \mathrm{mM}$ Tris- $\mathrm{HCl}, \mathrm{pH}$ 8.0). The samples were then incubated at $60^{\circ} \mathrm{C}$ for $1 \mathrm{~h}$ to dissolve the inclusion bodies, centrifuged $\left(10,000 \times g, 30 \mathrm{~min}, 4^{\circ} \mathrm{C}\right)$ and the supernatant was purified by immobilized metal ion affinity chromatography (Ni-NTA agarose - Qiagen). The supernatant was mixed with the resin preequilibrated with lysis buffer and incubated at $4{ }^{\circ} \mathrm{C}$ for $1 \mathrm{~h}$ with gentle shaking. The protein-bound resin was first washed twice with wash buffer 8 $\mathrm{M}$ urea, $100 \mathrm{mM} \mathrm{NaH} \mathrm{PO}_{4}, 100 \mathrm{mM}$ Tris- $\mathrm{HCl}, \mathrm{pH}$ $6.3)$ and finally eluted with elution buffer $(8 \mathrm{M}$ urea, $100 \mathrm{mM} \mathrm{NaH}{ }_{2} \mathrm{PO}_{4}, 100 \mathrm{mM}$ Tris- $\mathrm{HCl}, \mathrm{pH}$ 4.5). After four cycles of dialysis for $12 \mathrm{~h}$ each in a proper buffer $(100 \mathrm{mM}$ Tris- $\mathrm{HCl}, 500 \mathrm{mM} \mathrm{NaCl}$, $0.5 \mathrm{mM}$ EDTA, $5 \mathrm{mM}$ DTT, $20 \%$ glycerol, $\mathrm{pH}$ $8.5)$, protein was analyzed by $15 \%$ SDS-PAGE, under reducing conditions. Proteins bands were visualized by staining with Coomassie Brilliant Blue. The concentration of the eluted protein was determined by the Bradford method using bovine serum albumin as standard (Bradford, 1976).

Western blot analysis was used to confirm the BrVP28 expression. The proteins separated by the SDS-PAGE were electro-transferred on to a nitrocellulose membrane (Bio-Rad) in transfer buffer $(25 \mathrm{mM}$ Tris, $192 \mathrm{mM}$ glycine, $20 \% \mathrm{v} / \mathrm{v}$ methanol, $\mathrm{pH}$ 8.3). The membrane was blocked with $5 \%$ nonfat dry milk in phosphate buffered saline (PBS) containing $0.1 \%(\mathrm{v} / \mathrm{v})$ Tween20 at room temperature for $1 \mathrm{~h}$. The transferred proteins on nitrocellulose were incubated for $90 \mathrm{~min}$ with mouse anti-HisTag monoclonal antibodies (Sigma)
$(1: 5,000)$, washed 5 times in PBS and then incubated with peroxidase-conjugated goat antimouse total immunoglobulin (Sigma) $(1: 10,000)$ for $1 \mathrm{~h}$. The recombinant protein was detected using an ECL kit, according to the manufacturer's protocol (GE Healthcare).

\section{RESULTS AND DISCUSSION}

WSSV protein was cloned and expressed aiming to contribute to understand the process of viral biology, as well for development of diagnostic methods, as an attempt to contain the WSSV spread. The VP28 carboxyl-terminal hydrophilic region was successfully expressed in E. coli and further purified. To our knowledge, this is the first report regarding the production a WSSV recombinant protein from a strain isolated in Brazil. The amplification of the interest region by PCR resulted in a fragment of 558 bp (Fig. 1).

This fragment lacked the amino-terminal transmembrane nucleotide coding sequence (Fig. 2 ). The transmembrane region was particularly hydrophobic and could limit the production and further purification of recombinant proteins (Tang et al., 2007; Xie et al., 2006). A truncated version of the VP28 protein was also employed by Witteveldt et al. (2004) using pET-28a as expression vector, resulting in a protein of approximately $28 \mathrm{kDa}$, which was used to develop an oral "vaccine" against WSSV for the shrimps. A Blast search indicated that the amplified product of $558 \mathrm{bp}$ had homology with other VP28 sequences from different WSSV strains. The deduced amino acid sequence of the BrVP28 displayed high amino acid identities (98-100\%) with WSSV isolates from India (GenBank: DQ681069; DQ013881; DQ013882; DQ013883), Korea (GenBank: AY324881), Japan (GenBank: AY249443), Indonesia (GenBank: AY249441) and China (GenBank: AY249440). However, the obtained deduced amino acid sequence of BrVP28 showed less identity (about 90\%) with the VP28 protein from a Mexican strain (GenBank: EU931451) (Fig. 3). The sequence data was submitted to GenBank with the accession number HQ130032. The significant identity of the VP28 gene between the Brazilian strain and WSSV isolates from other countries indicated the highly conserved nature of WSSV proteins worldwide. 


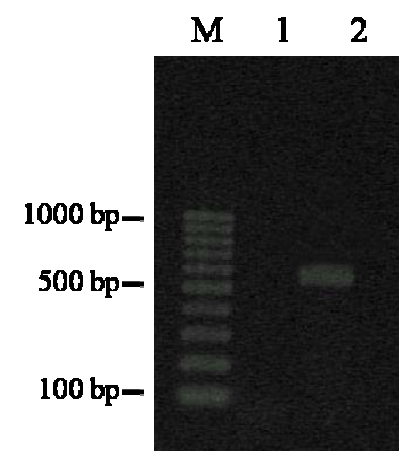

Figure 1 - PCR amplification of a fragment of the VP28 gene. A 1\% agarose gel electrophoresis stained with ethidium bromide, revealing the PCR amplification product of $558 \mathrm{bp}$ corresponding to a fragment of the VP28 gene. M: marker (100 pb DNA ladder); (1) negative control (PCR reaction without DNA); (2) amplification of the BrVP28 from WSSV infected shrimp genomic DNA.

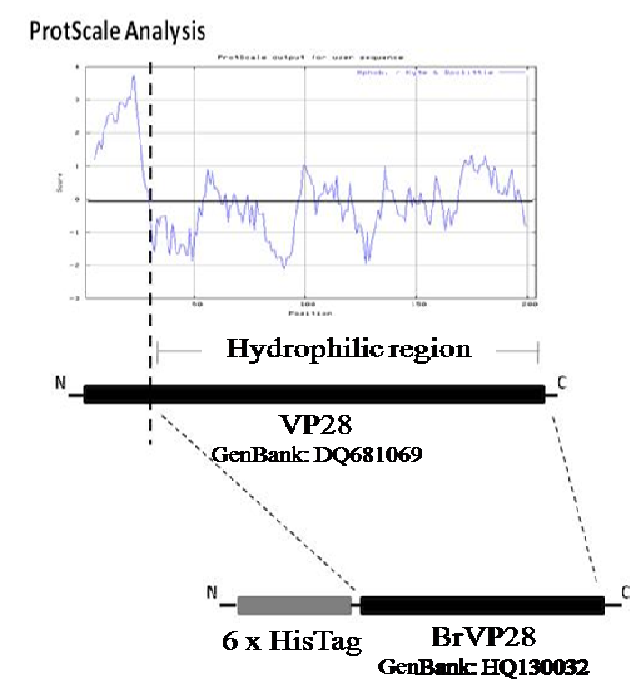

Figure 2 - Design of BrVP28 production. The prediction of the hydrophobic amino-terminal region was performed by ProtScale software using the VP28 protein from an Indian WSSV strain as template (GenBank: DQ691069). The BrVP28 recombinant protein comprises a 6-histidine tag at the amino-terminal region.

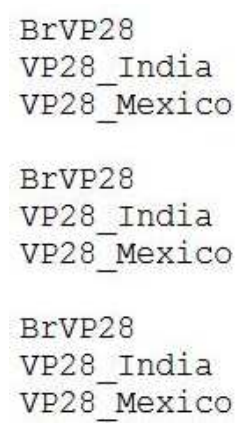

Figure 3 - Alignment of the deduced amino acid sequence of BrVP28 with homologous sequences of VP28 isolates from India (GenBank: DQ681069) and Mexico (GenBank: EU931451). Amino acid residues that are absent in the Mexican sequence are highlighted. 
This finding was in agreement with a previous report that described the conservation of the major structural WSSV viral proteins (You et al., 2004). The recombinant BrVP28 protein was obtained using the plasmid pET14b-BrVP28, which was used to transform $E$. coli BL21(DE3)pLysS cells. To optimize the production of the BrVP28, different culture conditions were tested, such as temperature, induction stage and IPTG concentration. The best recombinant expression levels were achieved after $4 \mathrm{~h}$ of induction with 1 $\mathrm{mM}$ of IPTG at $37^{\circ} \mathrm{C}$. A band of approximately 21 $\mathrm{kDa}$ was observed in the protein pattern of clones induced with IPTG, but absent in those notinduced (Fig. 4A). The BrVP28 protein produced was in the form of a recombinant fusion protein with a 6-histidine tag at the amino-terminal region. The lacking of the transmembrane region resulted in a recombinant fragment smaller than the native VP28 protein.

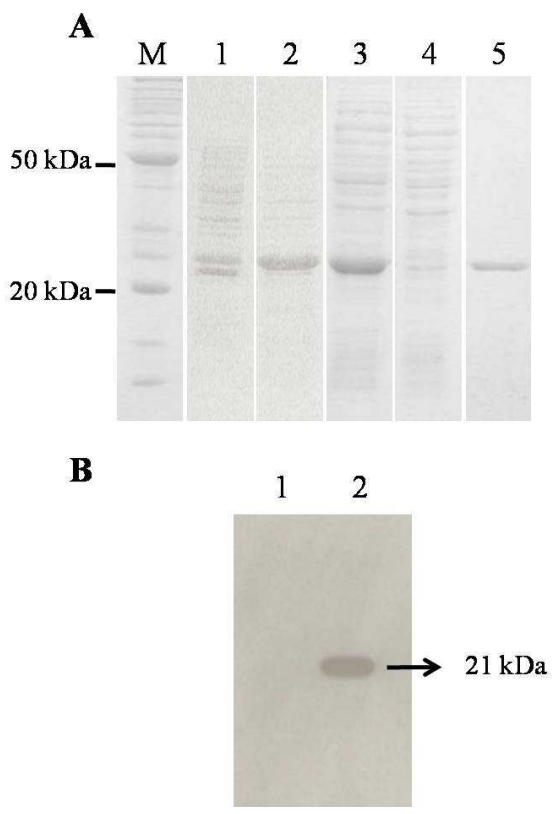

Figure 4 - Heterologous expression of the BrVP28 recombinant fragment of the VP28 protein evaluated by SDS-PAGE and Western blotting. (A) Coomassie stained SDS-PAGE showing the total protein profile of E. coli BL21(DE3)pLysS expressing the recombinant protein BrVP28. (B) Western blotting analysis of histidine-tagged BrVP28. M: Protein molecular weight marker $(\mathrm{kDa}), 1$ : E. coli transformed with pET14b-BrVP28 plasmid before IPTG induction; 2 : E. coli transformed with pET14bBrVP28 plasmid after $4 \mathrm{~h}$ of IPTG induction; 3: insoluble and 4: soluble fractions of the $E$. coli expressing BrVP28 after induction; 5: Purified BrVP28.

The protein purification was performed under denaturing conditions using immobilized metal ion affinity chromatography, and $\mathrm{pH}$ gradient for protein elution. Under denaturing conditions, this procedure was more effective for insoluble protein purification than adding the competitors such as imidazole, and also was the method recommended by the manufacturer of the expression system. Some studies have reported the purification of recombinant proteins from acrylamide gel slab (Chaivisuthangkura et al., 2004), but the histidinetagged protein purification protocol used in the present work was relatively simpler and provided a pure preparation without bacterial protein contaminants. Using this method of purification, a final protein yield between 128 to $241 \mu \mathrm{g} / \mathrm{ml}$ was achieved.

Western blotting analysis of the bacterial culture before and after IPTG induction using anti-HisTag monoclonal antibodies revealed the presence of the BrVP28-histidine fusion protein only in the induced E. coli cultures (Fig. 4B). The Western blot analysis confirmed the success of the BrVP28 expression using the protocol developed. Results obtained in this study showed for the first time the production of a WSSV protein from a Brazilian 
isolate. This recombinant protein can be used as antigen for poly and monoclonal antibody production, which can be employed in the development of diagnostic tools, as well in studies of characterization of WSSV strain.

\section{ACKNOWLEDGMENTS}

This work was supported by grants from Conselho Nacional de Desenvolvimento Científico e Tecnológico (CNPq) and Financiadora de Estudos e Projetos (FINEP).

\section{REFERENCES}

APHIS-USDA. Natural Resources Research. (2005), Impact worksheet white spot disease in Brazil. Available at: http://www.aphis.usda.gov/vs/ceah/cei/taf/iw_2005_f iles/foreign/whitespot_brazil_012705_files/Whitespot diseaseBrazil012105.htm. Accessed April 2009.

Bradford, M.M. (1976), A rapid and sensitive method for the quantification of microgram quantities of protein utilizing the principle of protein-dye binding. Anal Biochem., 72, 248-254.

Chaivisuthangkura, P.; Tangkhabuanbutra, J.; Longyant, S.; Sithigorngul, W.; Rukpratanporn, S.; Menasveta, P.; Sithigorngul, P. (2004), Monoclonal antibodies against a truncated viral envelope protein (VP28) can detect white spot syndrome virus (WSSV) infections in shrimp. Sci. Asia, 30, 359-363.

Flegel, T.W. (2007), Update on viral accommodation, a model for host-viral interaction in shrimp and other arthropods. Dev. Comp. Immunol., 31, 217-231.

Lightner, D.V. (2003), The penaeid shrimp viral pandemics due to IHHNV, WSSV, TSV and YHV. History in the Americas and current status. $32^{\text {nd }}$ Aquaculture Panel Meeting, California, USA, p. 120.

Liu, H.; Söderhäll, K.; Jiravanichpaisal, P. (2009), Antiviral immunity in crustaceans. Fish Shellfish Immunol., 27, 79-88.

Lo, C.F.; Ho, C.H.; Peng, S.E.; Chen, C.H.; Hsu, H.C.; Chiu, Y.L.; Chang, C.F.; Liu, K.F.; Su, M.S.; Wang C.H.; Kou, G.H. (1996), White spot syndrome baculovirus (WSBV) detected in cultured and captured shrimp, crabs and other arthropods. Dis. Aquat. Organ., 27, 215-225.
Marks, H.; Goldbach, R.W.; Vlak, J.M.; van Hulten, M.C.W. (2004), Genetic variation among isolates of white spot syndrome virus. Arch. Virol., 149, 673-697. Robalino, J.; Payne, C.; Parnell, P.; Shepard, E.; Grimes, A.C.; Metz, A.; Prior, S.; Witteveldt, J.; Vlak, J.M.; Gross, P.S.; Warr, G.; Browdy, C.L. (2006), Inactivation of white spot syndrome virus (WSSV) by normal rabbit serum: implications for the role of the envelope protein VP28 in WSSV infection of shrimp. Virus Res., 118, 55-61.

Sambrook, J.; Fritsch, E.F.; Maniatis, T. (1989), Molecular cloning: A Laboratory Manual. Cold Spring Harbor NYS.

Tang, X.; Wu, J.; Sivaraman, J.; Hew, C.L. (2007), Crystal structures of major envelope proteins VP26 and VP28 from white spot syndrome virus shed light on their evolutionary relationship. J. Virol., 81, 67096717.

van Hulten, M.C.W.; Witteveldt, J.; Peters, S.; Kloosterboer, N.; Tarchini, R.; Fiers, M.; Sandbrink, H.; Lankhorst, R.K.; Vlak, J.M. (2001), The white spot syndrome virus DNA genome sequence. Virology, 286, 7-22.

Wang, X.; Zhan, W. (2006), Development of an immunochromatographic test to detect White Spot Syndrome Virus of shrimp. Aquaculture, 225, 196200.

Witteveldt, J.; Cifuentes, C.C.; Vlak, J.M.; van Hulten, M.C.W. (2004), Protection of Penaeus monodon against white spot syndrome virus by oral vaccination. J. Virol., 78, 2057-2061.

Xie, X.; Xu, L.; Yang, F. (2006), Proteomic analysis of the major envelope and nucleocapsid proteins of white spot syndrome virus. J. Virol., 80, 1061510623.

Yi, G.; Wang, Z.; Qi, Y.; Yao, L.; Qian, J.; Hu, L. (2004), VP28 of shrimp white spot syndrome virus is involved in attachment and penetration into shrimp cells. J. Biochem. Mol. Biol., 37, 726-734.

You, Z.; Nadala, E.C.; Yang, J.; Loh, P.C. (2004), Conservation of the DNA sequences encoding the major structural viral proteins of WSSV. Dis. Aquat. Organ., 61, 159-163. 